\title{
Synchronization in Chains of Material Particles with Non-linear Features
}

\author{
Julijana D. Simonovic \\ Doctor of Tehnical Sciences \\ University of Nis \\ Faculty of Mechanical Engineering
}

The paper presents the marvelous possibilities of identical synchronization in the dynamics of the chains of material particles. The nature of coupling elements between particles has got damped, linear and non-linear elastic properties. The one or more particles in the chain are periodically forced. Depending of coupling elements features and the positions of excitations the synchronization effect is less or more present. The multi-parameters analyses were done by presentation of numerical simulation in the phase space of output variables of coupled particles. Concluding remarks have been considered about nature of coupling and symmetries in system of the external excitation positions that are necessary and enough for reaching the identical synchronization threshold.

Keywords: chain of material particles, coupling elements, identical synchronization, synchronization threshold, , multi-parameters analyses.

\section{INTRODUCTION}

It would not be too much of an exaggeration to say that oscillations are one of the main forms of motion. They range from the periodic motion of planets to random openings of ion channels in cell membranes. The chain of material particles coupled with elastic and damped elements periodically forced performs oscillatory motions with all characteristic phenomena like as dynamical absorption, resonance, beating, modulations, synchronisations and could be used like a model of various natural phenomena. Nature is not based on isolated individual systems. It is rich in connections, interactions and communications of different kinds that are complex beyond belief. With this, synchronization is the most fundamental phenomenon associated with oscillations. Chains of material particles with non-linear coupling are systems with pronounced nonlinear characteristics. When one couple material particles that oscillates a lot of things can happen. For example, oscillations can stop altogether, which might be good sometimes, but occasionally disastrous. Or they could become totally unpredictable-but you might like it nevertheless because it looks beautiful. But the phenomenon which is most often associated with synchronization is the change of the time scales of interacting systems: if one couples the systems cleverly, they can start to oscillate "syn-chronously," which means "sharing the same time" [1].

The nonlinearity brings the properties of exponentially divergence of trajectories of particles that starts from very close points in phase space, nevertheless even in that systems on may find synchronization, which is rather surprising detail [1-2]. In the general sense the synchronization consider the correlation or mutual response in time behaviour of two or more processes. In other words, regimes of

Received: May 2014, Accepted: November 2014

Correspondence to: Julijana Simonovic

University of Nis Mechanical Engineering Faculty,

Medvedeva A. 14, 18000 Nis, Serbia

E-mail: bjulijana@masfak.ni.ac.rs subsystems have to coincidence after some period of time [3-4]. One can say that synchronization is the most fundamental phenomenon that occurs in oscillating processes. In most general terms, synchronization can be defined as an adjustment of the time scales of oscillations due to interaction between the oscillating processes, [5].Investigation of dynamics of chains of material particles in the systems with more than three degrees of freedom, even in the field of classical and linear chain forced dynamics, is important not only for mechanical signal processing, but also for electrical signal processing and signal filtering, for processing biodynamical signals in life systems (DNA double helix chains [6], biodynamical chain oscillators [7-8]) and also for university teaching and integrations of scientific results in different scientific fields.

This paper presents possibilities of identical synchronization (IS) in the non-linear chains of material particles. First of all we present model of synchronization of two material particles coupled with damped and linear and non-linear elastic elements that is mathematically tractable. Our experience tells us that models with the latter property are exceptional. While the treatment of just a two coupled elements can be done within the framework of non-linear dynamical systems, the description becomes much more complicated for a large number of such elements. Considering that in the next section we use multiparametric numerical simulations by using the possibilities of the Mathematica software for crossed chains with nine material particles. Depending of values of coupling coefficient and the positions of the external excitation the effect of synchronization is less or more present. After all, few conclusions about the nature of coupling like as necessary strength of coupling coefficients which is needed and enough for IS in the particular chain systems were discussed.

From all different cases of synchronization the identical synchronization (IS), as a particular case of general synchronization, was been of interest in this paper as in the paper [9]. The most simply case of IS could be bring off when the particles are coupled with sufficient 
coupling strength so that their states are equal after transient changes.

The work was originally presented on the 1st International Symposium on Machines, Mechanics and Mechatronics (SMMM 2014), on July 1-2. 2014, University of Belgrade, Faculty of Mechanical Engineering,Serbia.

\section{MATHEMATICAL MODELING}

Mathematical modelling can assist in formulating hypotheses and finding the experiments that may differentiate between different mechanisms, can help in determining which of the assumed mechanisms is likely to be most important for the observed effects. Finally, and perhaps most importantly, mathematical modelling is the tool for synthesis-the process of combining separate elements in order to form a coherent wholeallowing reconstruction of the function of phenomena as a whole based on the acquired knowledge of elementary processes.

The basic model of forced non-linear oscillations of two material object with mass $m_{1}$ and $m_{2}$ that are coupled with elements of damped and elastic properties, Fig.1. The elastic coupling element has both linear and nonlinear parts, the non-linear part is introduced like a nonlinearity of third order.

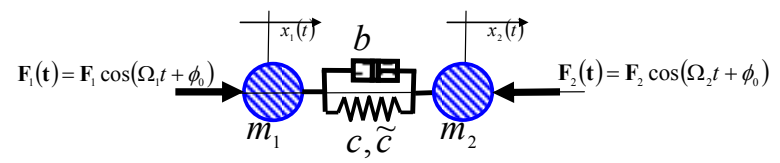

Figure 1. Periodically forced chain of two material particles coupled with an element with damped, linear and nonlinear properties.

The system of the two coupled nonlinear differential equations that corresponde to this model is:

$$
\begin{aligned}
& \ddot{x}_{1}(t)-2 \delta_{1}\left(\dot{x}_{2}(t)-\dot{x}_{1}(t)\right)-\omega_{1}^{2}\left(x_{2}(t)-x_{1}(t)\right)=\varepsilon \beta_{1}\left[x_{2}(t)-x_{1}(t)\right]^{3}+f_{1}(t) \\
& \ddot{x}_{2}(t)+2 \delta_{2}\left(\dot{x}_{2}(t)-\dot{x}_{1}(t)\right)+\omega_{2}^{2}\left(x_{2}(t)-x_{1}(t)\right)=-\varepsilon \beta_{2}\left[x_{2}(t)-x_{1}(t)\right]^{3}-f_{2}(t)(1)
\end{aligned}
$$

where we use notation for the coefficients: of non-linear coupling $\varepsilon \beta_{i}=\tilde{c} / m_{i}$, of linear coupling $\omega_{i}^{2}=c / m_{i}$, of damped coupling. The functions of periodic excitation are $f_{i}(t)=\left(F_{i} / m_{i}\right) \cos \left(\Omega_{i} t+\alpha_{i}\right)$. Proposed forms of the solutions are:

$$
x_{i}(t)=\sum a_{s}(t) K_{2 i}^{s} \cos \Phi_{s}(t)
$$

With the unknown time depended amplitudes $a_{s}(t)=R_{s}(t) e^{-\hat{\delta}_{i} t}$ and phase $\Phi_{s}(t)=\Omega_{s} t+\phi_{s}(t)$, where are: $K_{2 i}^{s}$ co-factors of determinant corresponding to basic homegenous coupled system,$-\hat{\delta}_{i}$ and $\hat{p}_{i}$ are real and imaginary parts of the appropriate pair of the roots of the characteristic equation (see Ref. [10]). Amplitudes $a_{s}(t)$ and phases $\Phi_{s}(t)$ may be obtained by using the Krilov-Bogolyubov-Mitropolyskiy asymptotic method, if it was taken into account that defined task satisfies all necessary conditions for applying asymptotic method Krilov-Bogolyubov-Mitropolskiy concerning small parameter $\varepsilon$. The system of the first order differential equations according to unknown amplitudes and phases in the first asymptotic averaged approximation [10] may be rewriten in the general form as follow:

$$
\begin{aligned}
& \dot{a}_{1}(t)=-\delta_{1} a_{1}(t)-\frac{\varepsilon \mathrm{P}_{1}}{\left(\Omega_{1}+\hat{\mathrm{p}}_{1}\right)} \cos \phi_{1} \\
& \dot{\phi}_{1}(t)=\left(\hat{\mathrm{p}}_{1}-\Omega_{1}\right)-\frac{3}{8} \frac{\alpha_{1}}{\hat{\mathrm{p}}_{1}} a_{1}^{2}(t)-\frac{1}{4} \frac{\beta_{1}}{\hat{\mathrm{p}}_{1}} a_{2}^{2}(t)+\frac{\varepsilon \mathrm{P}_{1}}{\left(\Omega_{1}+\hat{\mathrm{p}}_{1}\right) a_{1}(t)} \sin \phi_{1} \\
& \dot{a}_{2}(t)=-\delta_{2} a_{2}(t)-\frac{\varepsilon \mathrm{P}_{2}}{\left(\Omega_{2}+\hat{\mathrm{p}}_{2}\right)} \cos \phi_{2} \\
& \dot{\phi}_{2}(t)=\left(\hat{\mathrm{p}}_{2}-\Omega_{2}\right)-\frac{3}{8} \frac{\alpha_{2}}{\hat{\mathrm{p}}_{2}} a_{2}^{2}(t)-\frac{1}{4} \frac{\beta_{2}}{\hat{\mathrm{p}}_{2}} a_{1}^{2}(t)+\frac{\varepsilon \mathrm{P}_{2}}{\left(\Omega_{2}+\hat{\mathrm{p}}_{2}\right) a_{2}(t)} \sin \phi_{2}
\end{aligned}
$$

The full forms of constants $\delta_{i}, \alpha_{i}, \beta_{i}$ and $P_{i}$ could be find using the proposed method. Here it was underlined that these constants all rely on coefficients of coupling properties via cofactors $\mathrm{K}_{2 i}^{(s)}$, that $\delta_{i}$ depends of damping coefficients of visco-elastic layer, $\widetilde{\delta}_{(i)}$ and $\varepsilon \mathrm{P}_{i}$ depend of excited amplitudes, and $\alpha_{i}, \beta_{i}$ of non-linearity layer properties. Coefficients $\beta_{i}$ are coefficients of mode mutual interactions. When we finally find the closed forms of solutions then we are in position to make conclusions about IS. If we denoted with $\left(x_{1}, \dot{x}_{1}, \ldots\right)$ and $\left(x_{2}, \dot{x}_{2}, \ldots\right)$ the sets of dynamics variables which corresponds to the states of first and second oscillators, respectively, than the identical synchronization occurs when, for sets of initial conditions $\left(x_{1}(0), \dot{x}_{2}(0), \ldots\right)$ and $\left(x_{2}(0), \dot{x}_{2}(0), \ldots\right)$, the difference of state variables $\left|x_{2}(t)-x_{1}(t) \rightarrow 0\right|$ when time $t \rightarrow \infty$ or in the form:

$$
\lim _{t \rightarrow \infty}\left(x_{2}(t)-x_{1}(t)\right)=0 \text {. }
$$

This practically means that after enough period of time the dynamics of oscillators becomes the same $x_{i+1}(t)=x_{i}(t)$ for $i=1,2, \ldots, n$ in proper approximation. This equality in the unique state space presents subspace (diagonal), and that equality represents convergence of space vector $x(t)$ to that diagonal set $\left\{x: x_{i+1}=x_{i}\right\}$, [4].

While the treatment of just a two coupled elements can be done within the framework of non-linear dynamical systems, the description becomes much more complicated for a large number of such elements.

The next model of interests is the model of chain lattice composed of the four chains with eleven material particles. The chains are orthogonally crossed on the third and the ninth particles noted as a knots, so there is two horizontal and two vertical chains, Fig. 2. Now we have forty four coupled equations of motions in the form:

$$
\begin{gathered}
m_{(u)} \ddot{u}_{i j}=c_{(u)}\left(u_{i+1 . j}-2 u_{i, j}+u_{i-1, j}\right)+\tilde{c}_{(u)}\left(u_{i+1 . j}-u_{i, j}\right)^{3}-\tilde{c}_{(u)}\left(u_{i, j}-u_{i-1 . j}\right)^{3}+ \\
+b_{(u)}\left(\dot{u}_{i+1 . j}-2 \dot{u}_{i, j}+\dot{u}_{i-1 . j}\right)+h_{U i, j} \cos \left(\Omega_{i j} t+\alpha_{i j}\right) \\
\text { for } i=1 . .4, j=1 \ldots .11
\end{gathered}
$$

\section{NUMERICAL SIMULATIONS OF IDENTICAL SYNCHRONIZATION}

To solve system of coupled differential equations (5)we were forced to use numerical simulation to obtain 
conclusions about possibilities of knots IS. We assume that horizontal and vertical directions of motion are independent, so for a general trajectory of knots motions we actually sum up the solutions from independent directions. For possible identical synchronization of vertical knots we are looking for the equality $x_{3}(t)+y_{3}(t)=u_{3}(t)+y_{9}(t)$ or $x_{9}(t)+v_{3}(t)=u_{9}(t)+v_{9}(t)$ and for possible synchronization of horizontal knots $x_{3}(t)+y_{3}(t)=x_{9}(t)+v_{3}(t)$ or $\quad u_{3}(t)+y_{9}(t)=u_{9}(t)+v_{9}(t)$ and similar for the opposite combinations of knots. We also can provide different direction and position of the external excitation by changing the angle of attack on the particles $\alpha_{i j}$ and also position of the forces itself, Fig. 2 .

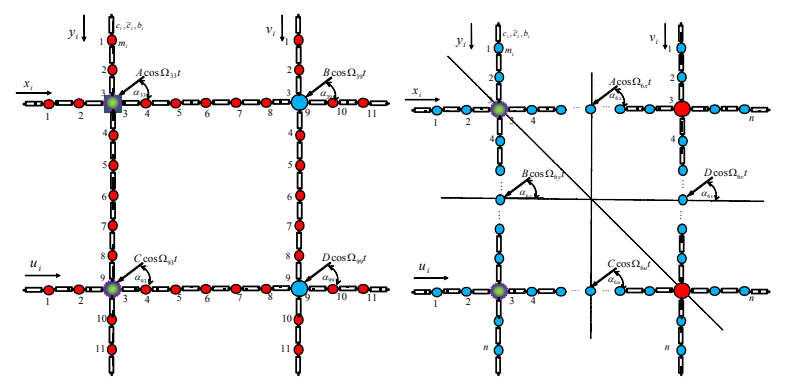

Figure 2. Crossed chains with knot external excitation or with excitation in the middle of the chains

In the left part of the Fig. 2 all four knots are attacked with external forces and we changed amplitudes and angles of attack like as values of coupling coefficients to synchronize them. The right part of the Fig. 2 presents possible attacks on the middles of the vertical chains, which perhaps give possibility of the diagonal symmetry of the lattice with synchrony of the opposite knots.

We were looking for the diagonal $x_{3}(t)+y_{3}(t)=u_{3}(t)+y_{9}(t)$ for exploration of synchronization of nodes on first vertical chain (nodes 33 and 39). That was naturally possible in the completely symmetric lattice when external excitations perform for notes in the same manner. The nodes adjust the resulting movements and the synchronization attractor is visible after transition changes, Fig. 3. But for the value of the coefficient of linear coupling larger than 2.08, Fig. 3, middle part, the diagonal attractor is possible; the identical synchronisation is reached after some initial period of time called synchronization time. By increasing the damping coefficient the synchronisation time is smaller, the nodes are synchronised faster when the coupling is with greater damping coefficient. The following observation was IS of the opposite nodes 33 and 99, Fig.4, for the same case of symmetrically excited lattice. Synchronization of opposite nodes is less possible even though for larger values of coefficient of linear coupling, upper part of the Fig.4. But only increasing the damping coefficient the IS emerges even for the less values of the coupling strength, lower part of Fig. 4 the diagonal of synchronisation is visible.

When lattice is not attacked symmetrically, for example when external excitation acts on nodes 33, 39 and 99, the IS is impossible, Fig.5. But after transition changes the different forms of phase synchronization are possible and the synchronization attractor is visible.
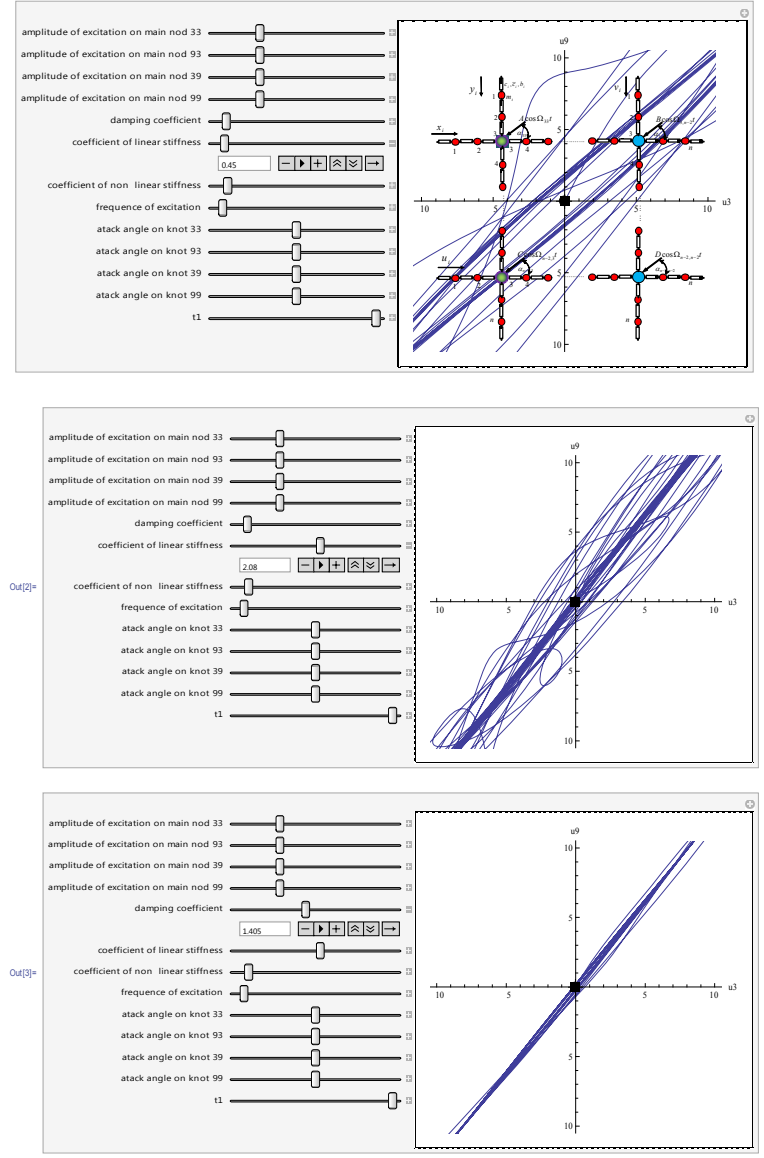

Figure 3. Synchronization attractors for knots from left vertical chain. External excitation acts on all four nodes.
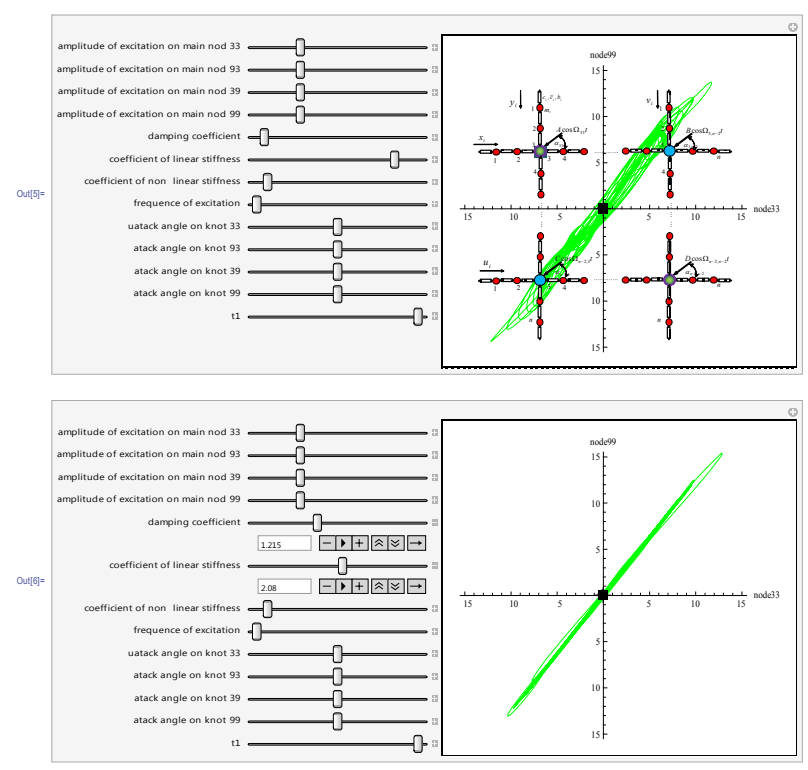

Figure 4. Synchronization attractors for opposite knots 33 and 99. External excitation acts on all four nodes.

The upper part of Fig.5 presents phase synchronisation $3: 1$, and the lower part phase synchronisation 1:1. By increasing coefficient of linear coupling the possibilities of synchronization increase after transition process, middle part of the Fig.5. Increasing the frequency of excitations, the phase locking 1:1 of nodes gets better possibilities. 

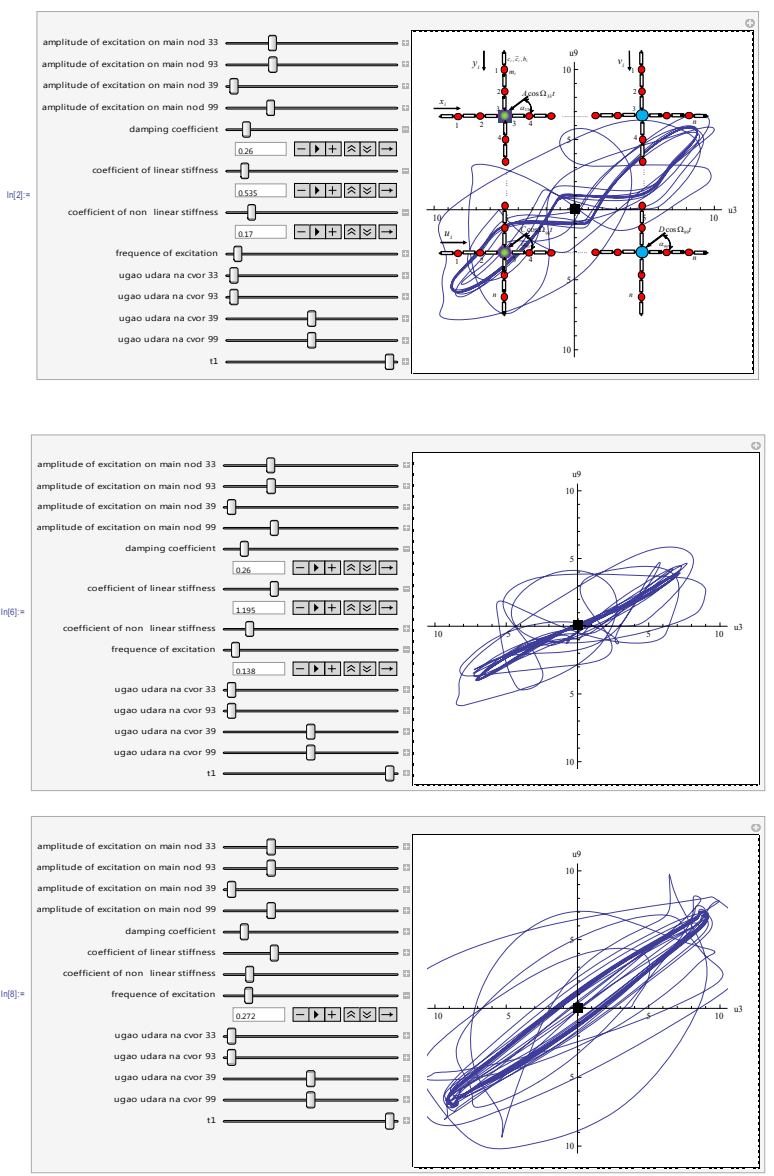

Figure 5. Synchronization attractors for knots from left vertical chain. External excitation acts on nodes 33; 93 and 99.
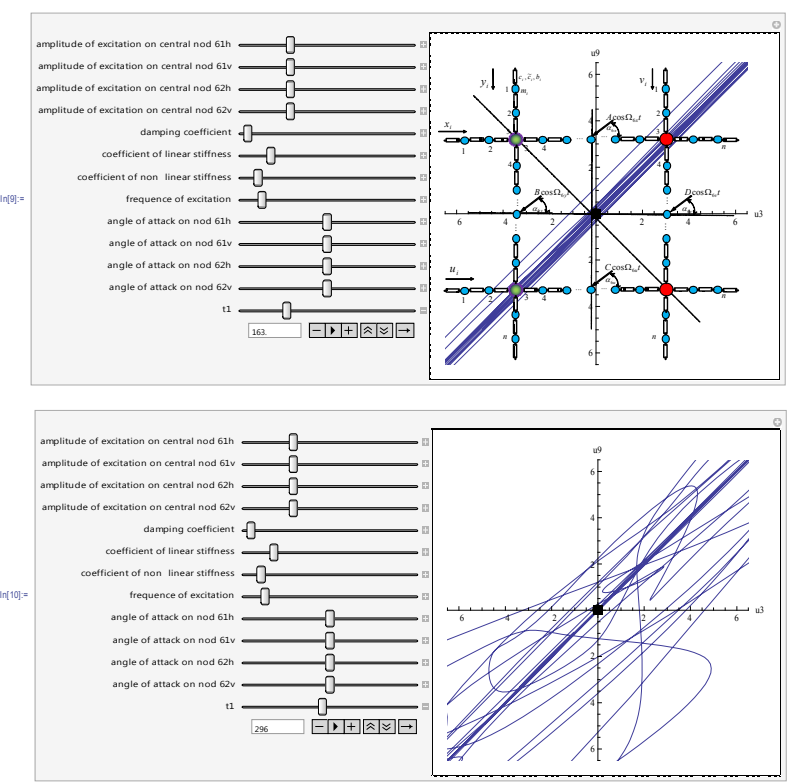

Figure 6. Synchronization of nodes on first vertical chain (nodes 33 and 39). External excitations act on middle dots in vertical and horizontal chains

For the case when external excitations act on the middle of the chains like it was presented on the right part of Fig. 2, we have interesting phenomena of initial synchronization of knots, the diagonal line that is visible in the beginning of the motion, Fig. 6 upper part. In initial periods nodes are synchronize but after some period of time lost IS, it is necessary that signal from external excitation from the middle of chain reachs to the node after some initial period and to disturb the synchrony. Increasing the time period we lost synchrony, Fig. 6 lower part.

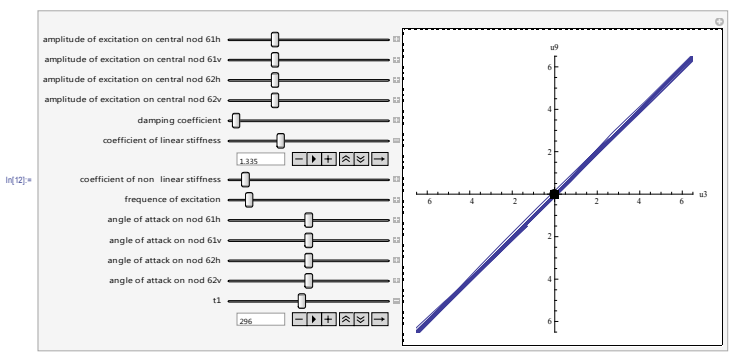

Figure 7. Identical synchronization of nodes on first vertical chain (nodes 33 and 39). External excitations act on middle dots in vertical and horizontal chains

By increasing coefficient of linear coupling the period of time in a synchrony of nodes is longer, Fig.7, we can notice that the period of time is the same like as on the lower part of Fig.6, but there is diagonal line representing IS because of the greater value of the coefficient of the linear coupling.

When nodes from vertical chains share the signal from the external excitation that acts on the middle point of vertical chain, Fig. 8, then the initial identical synchronization is possible with transition to phase synchronization. If we retain all parameters on the same values and only change the position of the external excitations that acts on the middle points of the horizontal chains, Fig. 9, then we find out identical synchronisation of left vertical nodes. This is due to the fact that excitation is symmetric in the latter case, and in the first case the influence of the signal from the parallel chains that has time delay causes the transition to phase synchronization.

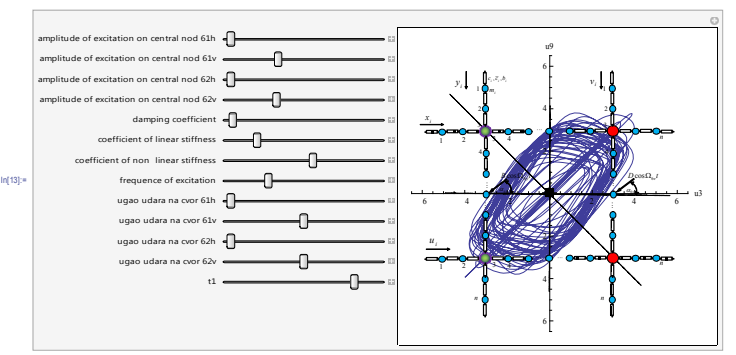

Figure 8. Identical synchronization of nodes on first vertical chain (nodes 33 and 39). External excitations act on middle dots in vertical chains

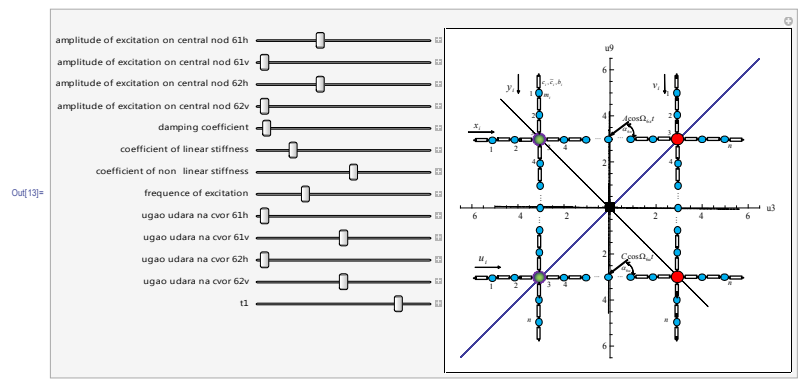

Figure9. Identical synchronization of nodes on first vertical chain (nodes 33 and 39). External excitations act on middle dots in horizontal chains 
The presented numerical simulation was performed to the identical synchronization mostly of the nodes from the left vertical chain, but all the given conclusions have relevance to synchronization of the other nodes.

\section{CONCLUSION}

The presented phenomenon of synchronization is very useful for elucidate the overall dynamics of large systems of material particles. The multi parametric computations (in silico) experiment is very useful tool for fast visual and parameter analysis of identical synchronization threshold. In chains with non-linear coupling the nonlinearity brings the properties of exponentially divergence of trajectories of particles that starts from very close points in phase space, nevertheless herein was shown that even in that systems one may find synchronization, which is rather surprising detail.

The identical synchronisation of all four knots of the lattice is possible if every node is synchronized with the other three knots, furthermore it is possible to conclude about synchronization of all knots on the base of the three knots synchronization only if it the external excitations act on the symmetric position in the lattice. The possibilities for identical synchronisation are generally greater if the coefficients of coupling have greater values, but in some cases it is possible that we have ragged synchronization with increasing some parameters. On the base of these multi parametric numerical simulations it is easy to find out the needed and enough values of parameters for reaching IS, i.e. to find out synchronization threshold that varies with values of system parameter and with position and values of the external excitations. As it is shown, by measuring the synchronization times for different cases of excitations positions, that these simulations could be used for measure of signal processing in these models of chain lattices.

\section{ACKNOWLEDGMENT}

This research was sponsored by the research grant of the Serbian Ministry of Education, Science and Technological Development under the number ON 174001

\section{REFERENCES}

[1] Pikovsky, A.; Rosemblum, M.; Kurths, J.: Synchronization: A Universal Concept in Nonlinear Sciences. Cambridge University Press, ISBN 0521-53352-X, 2001.

[2] Fradkov A.L., Pogromsky A.Yu.: Introduction to control of oscillations and chaos. Singapore: World Scientific Publishers, 1998.

[3] González-Miranda, J. M.: Synchronization and Control of Chaos. An introduction for scientists and engineers. Imperial College Press. ISBN 1-86094488-4, 2004.

[4] Pecora, L.M., Carroll, T.L., Johnson, G.A., and Mar, D.J.: Fundamentals of Synchronization in Chaotic Systems, Concepts and Applications, Chaos, vol. 7, no. 4, pp. 520-543, 1997.

[5] Balanov et al.: Synchronization: From Simple to Complex. Springer-Verlag, 2009.

[6] Hedrih (Stevanović) K., Hedrih A.:Eigen modes of the double DNA chain helix vibrations, Journal of Theoretical and Applied Mechanics(JTAM),No. 1 (48),2010, p-p. 219-231, ISSN 1429-2955.

[7] Hedrih A., Hedrih(Stevanovic) K., BugarskiB.: Oscillatory Spherical net model of Mouse ZonaPellucida. Journal of Applied Mathematics and bioinformatics. 2013, vol.3, no.4, 225-268., ISSN: 1792-6602, Scienpress Ltd, 2013.

[8] Hedrih A.: Modelling oscillations of Zona Pellucida before and after fertilization. ENOC Young Scientist Prize, Paper. EUROMECH Newsletter 40, Dec. 2011, European Mechanics Society, 40, pp. 614.

[9] Simonović J.: Synchronization in Coupled Systems with Different Type of Coupling Elements, Differntial Equations and Dynamical Systems, Volume 21, Issue 1 (2013), Pp. 141-148, (C) Springer 2013.

[10] Hedrih K., Simonović J.: Non-linear dynamics of the sandwich double circular plate system, International Journal of Non-Linear Mechanics 45 (9),2010, p-p: 902-918.

\section{СИНХРОНИЗАЦИЈА У ЛАНЦИМА МАТЕРИЈАЛНИХ ТАЧАКА СА НЕЛИНЕАРНИМ СВОЈСТВИМА}

\section{Јулијана Д. Симоновић}

Рад представља прелепе могућности идентичне синхронизације у динамици системима ланаца материјалних тачака. Спрежући елементи између материјалних тачака имају својства пригушења, линеарне и нелинеарне еластичнисти. Једна или више материјалних тачака ланца је периодички побуђена. Ефекат синхронизације је мање или више изражен зависно од својстава спрежучих елемената. Више параметарска анализа је извршена у фазном простору излазних променљивих спрегнутих материјалних тачака. Закључна разматрања садрже напомене о природи спрежућих елемената и симетрији у систему позиција дејства спољашње побуде које су потребне и довољне да би се достигао праг идентичне синхронизације. 